\title{
Pelvic Hemorrhage
}

National Cancer Institute

\section{Source}

National Cancer Institute. Pelvic Hemorrhage. NCI Thesaurus. Code C158133.

Bleeding within the pelvic cavity. 